\title{
From consumers to energy citizens: Finns' readiness for demand response and prosumerism in energy policy making
}

\author{
Ilkka Ruostetsaari
}

Faculty of Management and Business, Tampere University, Tampere, Finland

Received 13 November 2019 Revised 30 January 2020 20 February 2020 2 March 2020 Accepted 25 March 2020

\begin{abstract}
Purpose - The purpose of this paper is to test the effects of citizens' support for two rival and opposing conceptions of political involvement, political consumerism and stealth democracy, on their attitudes about demand response (flexible consumption) and prosumerism (self-production) in the context of making of Finnish energy policy. Stealth democracy represents an established view on the role of citizens in energy policy making: the energy sector has traditionally been presented as a technocratic domain reserved for experts and businessmen. By contrast, political consumerism can be seen as an expression of "energy democracy".
\end{abstract}

Design/methodology/approach - The data is based on a postal survey and an internet survey that were conducted in 2016 among a random sample representing Finns who were between 18 and 75 years. The dependence of the support for demand response and prosumerism on the endorsement of political consumerism and stealth democracy will be tested statistically (Pearson chi-square).

Findings - The endorsement of demand response mainly depended statistically on citizens' attitudes towards political consumerism and stealth democracy. However, comparing electricity prices and changing electricity suppliers did not depend on adherence to political consumerism and stealth democracy. Nevertheless, in these cases, support was higher among the supporters of political consumerism than among supporters of stealth democracy. By contrast, the endorsement of prosumerism, for instance, in terms of factors that influence citizens' decisions to invest in electricity generation in their households, depended statistically on citizens' attitudes on political consumerism and stealth democracy.

Research limitations/implications - It might be that the variables used in this study to measure stealth democracy are not specific enough. More generally, Finns' willingness to support for stealth democracy may be based on or at least encouraged by the misunderstandings of democratic politics: more information is needed on the level of knowledge that citizens have about normative principles of democratic decision-making processes.

Practical implications - The implication of this study for energy policy making is that there are (at least in Finland) good preconditions for developing a decentralized energy system: citizens are ready to adopt a more active role as energy citizens in terms of demand response and prosumerism - irrespective of their

(C) Ilkka Ruostetsaari. Published by Emerald Publishing Limited. This article is published under the Creative Commons Attribution (CC BY 4.0) licence. Anyone may reproduce, distribute, translate and create derivative works of this article (for both commercial \& non-commercial purposes), subject to full attribution to the original publication and authors. The full terms of this licence may be seen at http://creativecommons.org/licences/by/4.0/legalcode

This study has been funded by the Strategic Research Council at the Academy of Finland, Project "Transition to a resource efficient and climate neutral electricity system (EL-TRAN)", Grant Number 293437. response and

prosumerism 
attitudes on macro-level attitudes on governmental institutions. Democratization of the energy system could strengthen the legitimacy of energy policy making.

Social implications - Citizens' attitudes indicate that their potential for involvement needs to be strengthened in the spirit of energy democracy: the idea of energy democracy needs to be seen in terms of the demand for increased accountability and democratization of the energy sector that was previously not seen as requiring public involvement and was most often depoliticized and dominated by technocrats. However, strengthening energy democracy through demand response and prosumerism is not without its problems: utilization of these devices requires a relatively large amount of resources which depend on the individuals' socio-economic position. Thus, energy democracy cannot replace but complement electoral participation as a form of energy policy involvement.

Originality/value - The contribution of this study is to fill a part of the research gap linking to ongoing energy transitions. As a socio-technical transition can take place only if citizens support and participate in it, we need to better understand citizens' attitudes on energy consumption and production and energy policy involvement. Citizens' attitudes on energy production and consumption are becoming more and more critical for managing the energy sector as a result of that the share of wind power and solar power is increasing in the energy system. In a decentralized energy system, citizens have to be prepared to change their modes of operation. To the best of the authors' knowledge, the originality of this study is to test the impact of citizens' political attitudes on the endorsement of demand response and prosumerism.

Keywords Energy production, Renewable energies, Demand-side management, Power purchase agreements

Paper type Research paper

\section{Introduction}

Purpose of the study

Modes of direct citizen involvement such as referendums, civic initiatives, deliberative democracy, online democracy and political consumerism (political involvement through consumption choices) have been introduced in practice in many countries. A common denominator underlying these direct modes of political involvement is a conviction that people would participate more actively if they were offered more effective ways to be politically involved. However, this viewpoint has been challenged by the theory of stealth democracy which argues that people want to withdraw from politics. They do not want to make political decisions themselves, and they do not want to provide much input to those who are assigned to make these decisions (Hibbing and Theiss-Morse, 2005).

The purpose of this study is to test the effects of citizens' support for two rival and opposing conceptions of political involvement, political consumerism and stealth democracy, on their attitudes about demand response (flexible consumption) and prosumerism (self-production) in the context of making of Finnish energy policy. Stealth democracy represents an established view on the role of citizens in energy policy making: the energy sector has traditionally been presented as a technocratic domain reserved for experts and businessmen (Szulecki, 2017). By contrast, political consumerism can be seen as an expression of "energy democracy" that Szulecki (2017, p. 35) has defined "as an ideal political goal, in which the citizens are the recipients, stakeholders (as consumers/producers) and accountholders of the entire energy sectors policy".

This study is a continuation of our previous study that analysed the effect of citizens' social background on the endorsement of political consumerism and stealth democracy (Ruostetsaari, 2018), now focusing on citizens' attitudes on energy consumption and selfproduction. The data of the study is based on postal and internet survey conducted among Finns who were between 18 and 75 years in 2016.

The study focuses on energy policy, a societal sector where citizens' involvement was seen to be more limited than in most other policy domains (Chubb, 1983, pp. 258-259). Some 
firms, especially state-owned and more generally those operating in the energy supply, have had privileged access to decision-making arenas, which have remained mostly opaque for the citizens (Prontera, 2009, p. 23). Identical findings have been reported in Finland. The making of energy policy has been dominated by energy producers even though the voice of large energy-consuming firms has grown. Civic associations and consumer-citizens have had difficulty gaining access to the decision-making process on energy policy (Ruostetsaari, 2010, pp. 291-294).

The move from a centralized, mostly fossil fuel-based power sector, towards a decentralized energy system that includes a significant number of small and medium power producers affects the energy sector (Szulecki, 2017, p. 22). Citizens' attitudes on energy production and consumption are becoming more and more critical for managing the energy sector as a result of that the share of wind power and solar power is increasing in the energy system.

Thus, this transition requires a new type of governance, energy democracy, that is characterized by wide participation of informed, aware and responsible political subjects, in an inclusive and transparent decision-making process relating to energy choices, with the public good as its goal. Prosumers - and according to our interpretation, also the users of demand response - can be seen as idealized citizens of energy democracy (Sculecki, 2017, p. 35,32 ). Citizens' views on the potential of energy democracy have also been studied also in Finland with regard to prosumerism (Järvenreuna, 2019).

Finland is a particularly suitable platform for a critical test of political consumerism and stealth democracy in the context of energy consumption and production. Finnish political culture is characterized by an exceptional combination of citizen attitudes in international comparison. First, the voter turnout and civic efficacy (the sense that one can understand political processes and participate in them meaningfully) are low (Norris, 2011; KestiläKekkonen, 2014; Rucht, 1997; Rask, 2008). Second, popular trust in political, scientific and technological institutions is high (OECD, 2017; Eurostat, 2015; Eurobarometer, 2013; Science Barometer, 2016).

This mixture may have created incentives in the citizenry to look for alternative means for traditional political involvement, i.e. influencing energy policy through their own consumption choices (political consumerism), or leaving decision-making to experts rather than politicians (stealth democracy) (Ruostetsaari, 2018). In fact, Finland is one of the countries whose popular support for political consumerism is at the highest by international standards together with other Nordic countries, Switzerland and Germany (Stolle and Micheletti, 2013).

Finns' low civic efficacy touches also energy policy making. More than half the citizens were dissatisfied with their potential to influence energy policy; the proportion of the citizenry who agreed (fully or somewhat) with the statement that "citizens' opinions have not been heard sufficiently enough in energy policy decisions" was 71\% (mean) in 1983$1993,67 \%$ in 1994-2000 and 64\% in 2001-2007 (Energy Attitudes, 2007).

In short, the contribution of this study is to fill a part of the research gap linking to ongoing energy transitions. As a socio-technical transition can take place only if citizens support and participate in it, we need to better understand citizens' attitudes on energy consumption and production and energy policy involvement. It has been shown that the Finns are psychologically ready to engage in the energy transition, and they accept new actor roles in the energy system in 2017 (Vainio et al., 2019, p. 607). In a decentralized energy system, citizens have to be prepared to change their modes of operation. The study tests whether there is attitudinal readiness among the Finns to adopt a more active role as energy 
consumers and producers or do they trust more on energy experts in energy policy decisionmaking.

The study proceeds as follows. First, the concepts of demand response and prosumerism are defined and their roles in the Finnish energy policy making are outlined. Second, the data and research method are described. Third, the theoretical starting points dealing with political consumerism and stealth democracy are discussed. The hypotheses that direct the empirical analysis will be derived from this theoretical reflection. Fourth, the analysis is composed of two sections in which the effects of citizens' support for political consumerism and stealth democracy on their attitudes on demand response and prosumerism are analysed. Finally, conclusions are made based on empirical analysis and the findings are discussed in light of the theoretical starting points.

\section{Concepts of demand response and prosumerism}

Prime Minister Juha Sipilä's Government Program (2015-2019) set challenging targets for Finland to be reached by 2030: the share of renewable energy will rise to more than $50 \%$ of final energy consumption; energy self-sufficiency will increase to over $55 \%$; the use of coal in energy production will be terminated; the use of imported oil will be halved and the share of renewable fuels in traffic will rise to $40 \%$ (Valtioneuvosto, 2017).

To achieve these goals, the Energy and Climate Strategy for the period up to 2030 strives to promote the decentralized production of electricity and heat based on renewable energy. Most of the potential for small-scale electricity generation, in particular regarding solar power, is seen in residential real estates. Regarding small-scale wind power, the growth potential is seen particularly to be in areas located outside the electricity grids, especially in windy locations. Furthermore, efforts are being made to promote decentralized energy production in rural areas. To encourage decentralization of the Finnish energy system, the government is willing to increase consumers' participation in the planning of energy use as well as their readiness to demand response.

Demand response covers a wide range of activities such as influencing consumers' behaviour by indirect energy-pricing mechanisms, direct steering measures based on variable electricity prices and the guidance emanating from the needs of electricity grids (Järventausta et al., 2015). The growing need for demand response is raised especially by the increasing roles of wind and solar power in the energy system because their generation fluctuates sharply at different times of the day and year which increases the electricity price volatility (Ruostetsaari et al., 2018). According to governmental Energy and Climate Strategy, demand response plays a central role in improving energy efficiency to which consumers will be activated (Valtioneuvosto, 2017) [1].

Transition to an increasingly decentralized power production system implies a growing need for consumer-citizens to become consumer-producers, that is "prosumers". The concept of prosumer is built from the words "producer" and "consumer" (Toffler, 1980). The concept was generally linked to the media sector where consumers have for a long time been actively involved in the production of content for online services and innovation activities, generating added value and co-creation (Prahalad and Ramaswamy, 2004; Kotilainen, 2020).

European Commission refers to energy prosumers as "active consumers" and defines the concept as "a customer or group of jointly acting customers who consume, store or sell electricity generated on their premises, including through aggregators, or participate in demand response or energy efficiency schemes provided that these activities do not constitute their primary commercial or professional activity". Sometimes, energy prosumers are called "energy citizens" underlying their role as agents in the society. The energy citizens are seen as potential agents in supporting energy democracy (Sovacool and Blyth, 2015). 
Thus, the definition accentuates the participatory aspect of the prosumers as proactive consumers and citizens (Kotilainen, 2020; Szulecki, 2017).

Involvement in the demand response requires, at least to some extent, a change in consumption habits. However, this does not necessitate, for instance, compromising one's living comfort or moving around. In fact, established power companies and new service providers are planning ways in which households can be motivated to participate in demand response: for instance, the development of new pricing structures and market-places is a part of consumer activation (Ruostetsaari et al., 2018).

A prosumer can also be part of the demand response system of power companies by providing resources she or he owns (for instance, a water heater or an electric car battery) for the use of power companies or aggregators. In this case, the prosumer would be both "provider" and "consumer". An aggregator is a company that forms a larger entity composed of small consumers and small-scale production that can participate in the electricity market (Fingrid, 2018). However, in this study, energy citizens and prosumers refer to individuals or households, leaving larger prosumers and those of more commercial nature outside the definition (Kotilainen, 2020).

\section{Data and method}

A survey design was adopted in this study. The data is based on a postal survey and an internet survey that were conducted in 2016 among a random sample representing Finns who were between 18 and 75 years. A stratified sampling procedure ensures that the sample covers all socio-demographic groups and regions of Finland, excluding the province of Aland. Respondents' address information was purchased from The Population Register Center on 1 July 2016. The field work, covering one reminder round, was carried out in August-October 2016. The rate of response was relatively low $(33.6 \%)$, but it is quite typical for postal/internet surveys (Vainio et al., 2019). The large size of the sample $(N=4,000)$ ensures that the data adequately represent the Finnish population at large; hence, it is adequate for empirical analysis and generalizations (Ruostetsaari, 2018). The preliminary analysis of the data showed that there were no such deficiencies that would prevent a reliable analysis of the data.

However, the data deviates in minor respects from the population at large. A detailed loss analysis is presented in Table 1 . The gender distribution of the data corresponds well to that among the population but the youngest cohort of 18-29-year-olds is underrepresented, whereas citizens aged 45-59 and 60-75 years are clearly overrepresented. Compared to the population at large, the highly educated were overrepresented, whereas individuals with only basic education were underrepresented in the sample. In terms of educational fields, people from engineering and service branches were somewhat underrepresented. Regarding occupational positions, lower functionaries were underrepresented, whereas managers and upper functionaries, blue-collar workers and pensioners were somewhat overrepresented. Individuals living in detached houses were clearly overrepresented, and those living in apartment houses were underrepresented. In addition to the background variables listed in Table 1, people living in small municipalities were somewhat overrepresented, while those living in large municipalities were underrepresented. However, the respondents represented the various regions of the country (provinces) with an even distribution (Statistics Finland, 2016).

The items analysed in this study are a part of a longer survey focusing on citizens' energy attitudes. The analysed research questions and the response options are specified in the following text. The respondents will be divided into two dichotomous groups 


\section{IJESM}

\begin{tabular}{|c|c|c|c|}
\hline & Respondents in 2016 (n) & Respondents in $2016(\%)$ & Population in $2016(\%)$ \\
\hline \multicolumn{4}{|l|}{ Gender } \\
\hline Women & 657 & 49.6 & 50.7 \\
\hline Man & 674 & 50.4 & 49.3 \\
\hline \multicolumn{4}{|l|}{ Cohort (years) } \\
\hline $18-29$ & 143 & 10.9 & 14.6 \\
\hline $30-44$ & 260 & 19.7 & 18.7 \\
\hline $45-59$ & 354 & 27.0 & 19.6 \\
\hline $60-75$ & 556 & 42.4 & 19.6 \\
\hline \multicolumn{4}{|l|}{ Level of education } \\
\hline Only basic education & 245 & 9.4 & 29.8 \\
\hline Upper secondary & 504 & 40.7 & 40.5 \\
\hline Tertiary & 567 & 49.9 & 29.7 \\
\hline \multicolumn{4}{|l|}{ Field of education } \\
\hline Pedagogics/teacher training & 58 & 5.0 & 3.3 \\
\hline Humanities/arts & 50 & 4.3 & 5.6 \\
\hline Economics or social science & 222 & 19.0 & 21.0 \\
\hline Natural science & 36 & 3.1 & 2.7 \\
\hline Engineering & 324 & 27.8 & 33.0 \\
\hline Agriculture and forestry & 49 & 4.2 & 4.8 \\
\hline Social and health care & 159 & 13.6 & 15.5 \\
\hline Service branch & 100 & 8.6 & 13.5 \\
\hline Other & 169 & 14.5 & 0.4 \\
\hline \multicolumn{4}{|l|}{ Occupational position } \\
\hline Manager or upper functionary & 202 & 15.9 & 13.6 \\
\hline Lower functionary & 127 & 10.0 & 20.1 \\
\hline Entrepreneur & 113 & 8.9 & 6.3 \\
\hline Blue-collar worker & 299 & 23.5 & 16.5 \\
\hline Student & 60 & 4.7 & 6.9 \\
\hline Pensioner & 404 & 31.7 & 25.1 \\
\hline Other & 70 & 5.3 & 8.2 \\
\hline \multicolumn{4}{|c|}{ Size of the home municipality (residents) } \\
\hline Less than 4,000 & 78 & 6.0 & 4.5 \\
\hline $4,000-8000$ & 145 & 11.2 & 7.5 \\
\hline $8,000-30,000$ & 353 & 27.0 & 24.4 \\
\hline $30,000-80,000$ & 274 & 21.1 & 21.8 \\
\hline More than 80,000 & 456 & 34.8 & 41.6 \\
\hline \multicolumn{4}{|l|}{ Apartment type } \\
\hline Detached house & 657 & 49.3 & 39.2 \\
\hline Attached house & 238 & 17.9 & 13.7 \\
\hline Apartment house & 438 & 32.9 & 45.2 \\
\hline
\end{tabular}

(supporters/non-supporters) based on their attitudes towards items or statements (sum variable) reflecting political consumerism and stealth democracy. The dependence of the support for demand response and prosumerism on the endorsement of political consumerism and stealth democracy will be tested statistically (Pearson chi-square). This test indicates how likely the dependence is only caused by contingency in the sample so that the variables are independent of each other. The test will be carried out by using standard SPSS software. 


\section{Theoretical framework}

Political consumerism as a mode of political involvement

Scholars have argued that dissatisfaction and frustration with mainstream politics does not necessarily turn into political apathy. On the contrary, they argue that citizens have developed a multitude of ways to engage in politics outside the parliamentary arena that they find more suitable, responsible, efficient and direct for expressing their political interest and needs. In fact, citizens' willingness to participate in politics and societal affairs is still strong. One of these forms of involvement that relies on individualized responsibility-taking is political consumerism (Stolle and Micheletti, 2013, p. 33, 39; Stolle and Hooghe, 2006).

Political consumerism can be defined as "consumers" use of the market as an arena for politics to change institutional of market practices found to be ethically, environmentally or politically objectionable is a specific form of participation that characterizes individualized responsibility-taking. The concept shows that two traditions of consumption and citizenship, which tended to be located in opposing spheres of private and public, can today be seen increasingly as overlapping domains (Stolle and Micheletti, 2013, p. 39; Follesdahl, 2006).

From previous studies on political participation, it can be discerned two general findings to develop necessary theoretical conditions for the realization of individualized responsibility-taking, that is political consumerism. First, individual motivation is essential: citizens must be motivated both to seek and use sensitizing information to develop values in line with caring insights and to formulate preferences or an ethical compass that facilitates the making of reasonable choices. Second, citizens must feel that their actions matter. Therefore, they must have a sense of empowerment (or civic efficacy) to engage in the choice of practices associated with individualized responsibility-taking (Stolle and Micheletti, 2013, p. 24).

Respondents to our survey conducted in 2016 were asked how useful they perceived various devices were in influencing energy policy. The response options were "very useful", "fairly useful", "fairly useless", "totally useless" and "can't say" (Table 2).

Finns' perceptions of their potential to influence energy policy through consumption choices were very positive. The most useful devices were instructing children on energy issues and choosing energy-pinching appliances, which epitomizes so-called discursive political consumerism (Stolle and Micheletti, 2013; Micheletti, 2003).

It is noteworthy that that voting in elections (15th) and the modes that are termed here as participatory political consumerism, i.e. contacts with MPs (21st), acting in civic associations (17th), contacts with representatives of energy producing firms (18th) and contacts with public authorities (22nd), were ranked in 2016 as clearly less useful devices for influencing energy policy than other traditional forms of political consumerism (Ruostetsaari, 2018).

To figure whether the attitudes on political consumerism affect those on demand response and prosumerism, the respondents were divided into two dichotomous groups based on attitudes towards various devices listed in Table 2 . These groups were supporters (responding with "very" or "fairly useful") and non-supporters ("fairly" or "total useless" or "can't say") of political consumerism. We constructed a sum variable comprising all devices queried in 2016 (excluding "voting in elections", which represents conventional political participation).

Because realization of political consumerism requires that the citizenry must be both motivated to chance their consumption patterns and feel that their action matter in terms of energy policy, we hypothesize the following: 


\section{IJESM}

Device

Instructing children on energy issues 88

Choosing scantly spending/energy-pinching appliances $\quad 88$

$\begin{array}{lr}\text { Choosing eco-friendly products } & 87\end{array}$

Walking or cycling instead of driving $\quad 85$

$\begin{array}{ll}\text { Dropping or supervision of dwelling temperature } & 79\end{array}$

$\begin{array}{lr}\text { Using the so-called green electricity (produced by renewable energy) } & 79\end{array}$

$\begin{array}{lr}\text { Supervision of the use of electricity in the household } & 79\end{array}$

$\begin{array}{ll}\text { Reducing private driving by favoring public transport } & 77\end{array}$

Lowering personal consumption level in general $\quad 77$

$\begin{array}{lr}\text { Asking for competitive tenders from electricity companies } & 74\end{array}$

Reducing heating in leisure residence $\quad 64$

Reducing the use of sauna heated by electricity $\quad 62$

$\begin{array}{ll}\text { Reducing air travels } & 61\end{array}$

$\begin{array}{ll}\text { Reducing the use of consumer electronics } & 58\end{array}$

$\begin{array}{lr}\text { Voting in elections } & 56\end{array}$

Discussion on energy issues with other people/friends $\quad 48$

$\begin{array}{ll}\text { Acting in civic associations } & 30\end{array}$

Table 2. Contacts with representatives of energy producing firms 27

Usefulness (very or Writing letters about energy issues to the editors of newspapers 24

fairly useful) of Writing about energy issues on Internet discussion sites 23

various devices in Contacts with MPs $\quad 23$

influencing the Participation in demonstrations 10

Finnish energy Radical environmental activism 10

policy in $2016(\%) \quad N \quad 1,308$

H1. Supporters of political consumerism are more ready to implement activities of demand response than are non-supporters.

H2. Supporters of political consumerism are more ready to implement activities of prosumerism than are non-supporters.

View of stealth democracy on citizens' political involvement

The view of the theory of stealth democracy on citizens' political involvement is very different from that of political consumerism. While the view of political consumerism on citizens' willingness and potential for political involvement is positive, that of stealth democracy is more cynical.

Hibbing and Theiss-Morse argue that rather than wanting a more active participatory democracy, a remarkable share of people want what they call "stealth democracy". The concept is derived from aviation: stealth aircraft such as B-2 bombers are difficult to see with standard radar techniques, even if everyone knows they exists. In the same way, citizens want democratic procedures to exist but not to be visible on a routine basis. In fact, the last thing citizens want is to be more involved in political decision-making: they do not want to make political decisions themselves or provide much input to those who are assigned to make these decisions but prefer to spend their time in nonpolitical pursuits. Citizens want to distance them from government not because of a system defect but because they are averse to political conflict and believe that political conflicts are unnecessary and an 
indication that something is wrong with governmental procedures (Hibbing and TheissMorse, 2005, pp. 1-2, 7).

The theory argues that citizens are quite concerned with how government works, not just with what it produces: citizens' attitudes and behaviors are more affected by the process of government than by the policies government enacts, and policy performance explains little when it comes to public trust. In fact, we cannot fully understand people's attitudes towards government without taking into account how they think government ought to work and how they think government works in practice (Hibbing and Theiss-Morse, 2005, p. 6, 14, 25, 34, 81; Sovacool, 2013). The fact that citizens have preferences regarding policy process has also been shown in Finnish studies (Bengtsson and Mattila, 2009; Bengtsson, 2012).

Because of representatives, citizens do not need to be constantly bothering with a lot of issues about which they do not care. Elites are not what the citizenry fears but self-serving elites are. Because individuals are often too uninformed, unmotivated or narrow to exert political influence, non-self-interested decision makers, such as politicians, experts and businessmen should make the decisions for them. These decisions should be made efficiently, objectively and without commotion and disagreement (Hibbing and TheissMorse, 2005, p. 86, 127, 143).

To test whether Finns are willing to assign the decision-making on energy policy to experts representing public administration and business rather than elected officials, the respondents were asked a structured question as follows: "How great is the importance that you attach to following principles in energy policy-making?" The response options were "very important", "fairly important", "not really important", "not important at all" and "can't say" (Table 3). To test our hypotheses, we constructed a sum variable from five of the statements listed in Table 3. The statements depict the claim of stealth democracy as follows: "experts should be in charge of the drafting of decisions", "experts should be in charge of decision-making", "representatives of firms should take part in decision-making", "business organizations should play a central role in the decision-making" and "decisions should be made by consensus as a result of negotiations". The mean support (very" or "somewhat important") for the sum variable among the citizenry was $72 \%$, which exceeded support for representative democracy $(56 \%)$, i.e. the statement that "those politically responsible to the constituency should be in charge of decisions" as well as the endorsement of political consumerism (48\%) (Ruostetsaari, 2018).

Decision should be announced as openly as possible

Experts should be in charge of the drafting of decisions

Societal effects of decisions should be taken widely into account

Decisions should take account of various interest groups

Environmental effects of decisions should be taken widely into account

Those politically responsible to the constituency should be in charge of decision-making

The drafting process of decisions should be open

Citizens should be able to influence decisions

Experts should be in charge of decision-making

Representatives of firms should take part in decision-making

Business organizations should play a central role in decision-making

Decisions should be made by consensus based on negotiations

Environmental organizations should play a central role in decision-making

Energy policy should be determined free of governmental direction

Table 3.

The proportion of the citizenry who perceived very or somewhat important the principles concerning the process of energy policy making in $2016(\%)$ 
Popular support for four out of five of the aforementioned statements exceeded that for representative democracy, excluding one statement that "business organizations should play a central role in decision-making". Our finding that citizens were willing to see political power more in the hands of non-elected experts than businessmen was in agreement with Bengtsson and Mattila's (2009, p. 1040) survey conducted among Finns in 2007 (not focused on energy policy). They found that approximately $30 \%$ were in favour of giving power to more pronounced experts, while fewer than $20 \%$ wished to give more power to business leaders (Ruostetsaari, 2018).

Because the theory of stealth democracy argues that people do not want to play an active role in policy making but are willing to leave decisions to experts and businessmen, whom they trust more than politicians, we hypothesize the following:

H3. Supporters of stealth democracy are less ready to implement activities of demand response than are non-supporters.

H4. Supporters of stealth democracy are less ready to implement activities of prosumerism than are non-supporters.

Political consumerism and stealth democracy may be seen as opposite conceptions dealing with political involvement and conventional electoral participation. In fact, stealth democracy can be seen as a reaction among people who feel powerlessness in the face of the regime, while the supporters of political consumerism have a higher sense of civil efficacy, i.e. they feel that they can influence energy policy directly through their own activities rather than through representative democracy. Thus, we hypothesize that the following:

H5. Supporters of political consumerism are more ready to implement activities of demand response than are supporters of stealth democracy.

H6. Supporters of political consumerism are more ready to implement activities of prosumerism than are supporters of stealth democracy.

\section{Analysis}

Endorsement of demand response

Our survey showed that Finns are ready to bring new electricity solutions into use. When the respondents were presented with the following statement, "I am interested in trying out new solutions for using electricity", $18.6 \%$ agreed totally; $44.0 \%$ somewhat agreed; $18.2 \%$ somewhat disagreed; $7.9 \%$ disagreed totally with the statement, while $10.6 \%$ could not answer. As expected (H1), interest in new electricity solutions was highest among supporters of political consumerism: $71.9 \%$ of them agreed totally or somewhat with the statement, while the share of non-supporters agreeing was $55.5 \%(p=0.000)$. Contrary to the expectation (H3), interest in new solutions was higher (66.1\%) among supporters of stealth democracy than among non-supporters $(49.6 \%)(p=0.000)$. However, as expected (H5), supporters of political consumerism were more interested in new solutions than were supporters of stealth democracy.

By contrast, the comparison of electricity prices and changing of electricity suppliers did not depend statistically $(p>0.05)$ on the endorsement of political consumerism and stealth democracy. However, $74.0 \%$ of supporters of political consumerism had compared electricity prices between different suppliers, while the share of non-supporters having done was $71.4 \%$. Against expectation (H3), a larger share of supporters of stealth democracy $(72.8 \%)$ had compared prices than had non-supporters $(67.4 \%)$. The number of times the 
electricity supplier had been changed did not depend on the endorsement of political consumerism or stealth democracy. Of the supporters of political consumerism, $54.7 \%$ had changed their supplier at least once, while the share of non-supporters who had done so was $51.7 \%$. In terms of stealth democracy, the share was $52.5 \%$ among both supporters and nonsupporters.

Hourly based electricity contracts, which are important prerequisites for the utilization of demand response, are still rarities in Finland. Only 3.9\% of respondents had this kind of contract. A total of $21.9 \%$ had contracts based on different day-time and night-time pricing, while $57.0 \%$ had fixed-price contracts, and $14.4 \%$ did not know their electricity contract.

However, if the respondent did not yet have an hourly-based contract, their interest in it depended statistically on the endorsement of political consumerism $(\phi=0.000)$ and stealth democracy $(p=0.017)$. As expected (H5), supporters of political consumerism were more interested $(33.2 \%)$ than were non-supporters $(21.2 \%)$. Contrary to our expectation, supporters of stealth democracy were more interested $(28.6 \%)$ than were non-supporters $(22.4 \%)$. In line with our expectation, supporters of political consumerism were more interested in an hourly based electricity contract than supporters of stealth democracy.

If the respondent had an hourly based contract, its use depended statistically on the endorsement of political consumerism $(p=0.000)$ and stealth democracy $(p=0.008)$. Of the supporters of political consumerism, $19.1 \%$ said that they "always" strive to use electricity during hours when it is cheap, while the share of non-supporters who did so was $2.8 \%$. Among the supporters of stealth democracy, the share was $13.0 \%$, while none of nonsupporters used cheap hourly prices "always".

The respondents were also asked whether they would be prepared, with compensation, to set their apartments' room temperature two degrees lower than the current setting when nationwide electricity consumption is at its peak. There were only two response options: "yes" or "no". As expected (H1), $66.5 \%$ of supporters of political consumerism were ready to lower their room temperature, while the share of non-supporters ready to do so was $43.3 \%$ $(p=0.000)$. However, contrary to our expectation (H3), supporters of stealth democracy were more ready $(55.0 \%)$ to lower room temperature than were non-supporters $(49.8 \%)(p=$ 0.146). As expected (H5), supporters of political consumerism were more ready to do so than supporters of stealth democracy.

The respondents were presented with a structured question as follows, "Are you ready to take the following measures to reduce your energy bill" (Table 4). All these measures represent the demand response. The response were "very likely", "fairly likely", "fairly unlikely" and "very unlikely", of which the first two response options are combined in Table 4.

As we predicted (H1), supporters of political consumerism were more willing to take all measures to reduce their energy bills than were non-supporters. The dependence between the endorsement of political consumerism and readiness to take measures to reduce the energy bill was statistically significant $(\phi<0.001)$. Contrary to our expectation $(H 3)$, supporters of stealth democracy were not less willing to take the measures than were nonsupporters. In fact, supporters of stealth democracy endorsed all measures more often than non-supporters. However, there was a statistically significant dependence between the endorsement of stealth democracy and the measures in only five out of nine measures. Finally, our findings dealing with the difference between supporters of political consumerism and stealth democracy were consistent with our expectation that supporters of political consumerism are more ready to implement activities of demand response than are supporters of stealth democracy (H5). In other words, supporters of political consumerism 
IJESM

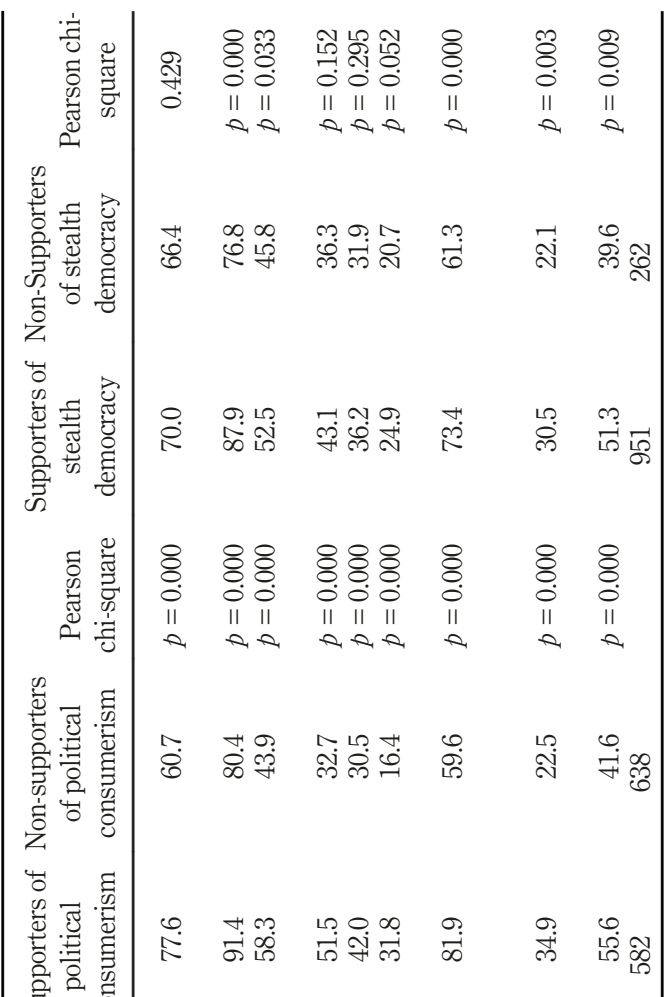

Table 4.

Respondents'

readiness (very or

fairly likely) to take

the following

measures to reduce

their own energy

bills (\%) 
were more ready to take all the measures listed in Table 4 than were supporters of stealth democracy.

\section{Endorsement of prosumerism}

The respondents to our survey were asked whether they were interested in investing electricity generation in their residence, leisure home or housing cooperative. Of the respondents $10.7 \%$ were very interested, and $23.9 \%$ were fairly interested, while $33.1 \%$ were just a little interested, and $32.4 \%$ were not interested at all. However, according to an internet panel study at the turn of the year 2016-2017, Finns' interest in the electricity generation was much higher when it was not connected to their own action. As many as three-fourths agreed fully or somewhat with the statement, "In Finland, there is a need to invest heavily in producing energy at homes" (Pitkänen and Westinen, 2017, p. 15).

Of the supporters of political consumerism, $44.7 \%$ were very or fairly interested in investing in electricity generation in their homes, while the share of non-supporters was $26.5 \%(p=0.000)$. This finding is congruent with our hypothesis $(H 2)$ that supporters of political consumerism are more ready to implement activities of prosumerism than are nonsupporters. The corresponding shares among supporters and non-supporters of stealth democracy were 36.5 and $27.5 \%$, respectively $(p=0.002)$. Thus, contrary to our expectation $(H 4)$, supporters of stealth democracy were more ready to implement activities of prosumerism than were non-supporters. However, consistent with the hypothesis, supporters of political consumerism were more ready to implement activities of prosumerism than were supporters of stealth democracy $(H 6)$.

Solar panels were a rarity among the respondents: $1.4 \%$ had a panel in their residence, while $6.6 \%$ had them in their leisure home. The respondents were asked whether they were interested in purchasing solar panels in their residence or leisure home: $42 \%$ were "very" or "fairly" interested. In line with our hypothesis (H2), a larger share of supporters (52.0\%) than non-supporters of political consumerism $(33.2 \%)(p=0.000)$ were interested in purchasing solar panels. The corresponding shares of supporters and non-supporters of stealth democracy were 43.7 and $34.4 \%$, respectively, which is not in line with our hypothesis $(H 4)(p=0.022)$. However, our findings supported the hypothesis concerning the relationship between the supporters of political consumerism and stealth democracy $(H 6)$.

Moreover, the respondents were asked as follows: "To what extent do the following factors influence your decision to invest in electricity generation in your household?" (Table 5). The response options were "very much", "fairly much", "quite a few", "not at all" and "can't say", of which the first two options were combined in Table 5.

Supporters of political consumerism attached more weight to all the factors listed in Table 5 than did non-supporters $(p<0.05)$, and supporters of stealth democracy perceived all factors as more important than did non-supporters $(\phi<0.05)$. These findings are in line with $H 1$ but contradicts $H 4$. The only factor in which there was not a statistical difference between the supporters and non-supporters of stealth democracy was "opportunity to test and provide feedback on new technical solutions". Again, our findings related to the endorsement of political consumerism and stealth democracy were in congruence with our H6.

\section{Conclusions \\ Results}

The purpose of this study was to test the effects of citizens' support for two rival interpretations of political involvement, political consumerism and stealth democracy, on their attitudes towards demand response and prosumerism in the context of the making of 
IJESM

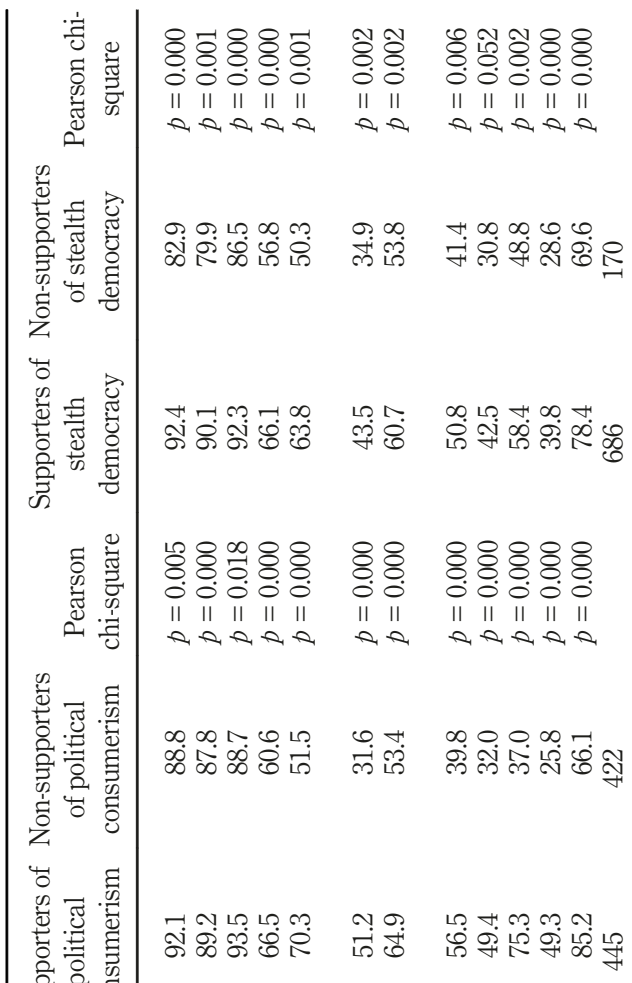

Table 5.

Factors that influence very or fairly much a respondent's decision to invest in electricity generation in her/his own household (\%) 
Finnish energy policy. Demand response refers to a change in the consumption behaviour of citizens, especially the transferring of electricity use from hours of peak consumption to cheaper times. Transition to an increasingly decentralized power production system implies not only a growing need for demand response but also a need for consumer-citizens to become consumer-producers, that is prosumers. A prosumer can is an active citizen who participates in various activities linked to production, consumption and delivery of energy.

The concept of political consumerism combines the two traditions of consumption and citizenship, which tended to be located in opposing spheres of private and public life (Follesdahl, 2006). Political consumers' choices are based on attitudes and values concerning issues of justice and fairness or noneconomic issues regarding personal and family wellbeing and ethical assessments of favorable business and governmental practices (Stolle and Micheletti, 2013).

For the realization of political consumerism to take place citizens must be both motivated to change their consumption patterns and feel that their action matter in terms of energy policy. Hence, we hypothesized that supporters of political consumerism are more ready to implement activities of demand response than are non-supporters (H1) and that supporters of political consumerism are more ready to implement activities of prosumerism than are non-supporters (H2). Both these hypotheses were verified in light of our empirical analyses (Table 4).

Contrary to political consumerism, the claim of stealth democracy is that people do not routinely play active roles in decision-making or in providing input to or monitoring decision makers. On the contrary, they are willing to leave decisions to experts and businessmen, whom they trust more than politicians. In fact, people want to distance themselves from government (Hibbing and Theiss-Morse, 2005). Hence, we hypothesized that the supporters of stealth democracy are less ready to implement activities of demand response than non-supporters $(H 3)$ and the supporters of stealth democracy are less ready to implement activities of prosumerism than are non-supporters $(H 4)$. Both these hypotheses were falsified: the endorsement of stealth democracy increased support for demand response and prosumerism (Table 5).

Political consumerism and stealth democracy may be seen as rival and opposite conceptions of political involvement and conventional electoral participation. In fact, stealth democracy can be seen as a reaction among people who feel powerlessness in the face of the regime, while the supporters of political consumerism have a higher sense of civil efficacy, i.e. they feel that they can influence energy policy directly through their own activities rather than through representative democracy. Thus, we hypothesized that the supporters of political consumerism are more ready to implement activities of demand response than are supporters of stealth democracy (H5), and supporters of political consumerism are more ready to implement activities of prosumerism than are supporters of stealth democracy $(H 6)$. Both these two hypotheses were verified.

All in all, the endorsement of demand response mainly depended statistically $(p<0.05)$ on citizens' attitudes towards political consumerism and stealth democracy. However, comparing electricity prices and changing electricity suppliers did not depend on adherence to political consumerism and stealth democracy. Nevertheless, in these cases support was higher among the supporters of political consumerism than among supporters of stealth democracy. By contrast, the endorsement of prosumerism, for instance, in terms of factors that influence citizens' decisions to invest in electricity generation in their households, depended statistically $(p<0.05)$ on citizens' attitudes on political consumerism and stealth democracy. 
Discussion

Now, it is important to ask why the findings dealing with the effects of stealth democracy deviated from our expectations. It was shown that along with political consumers, supporters of stealth democracy who are in general willing to leave decisions in energy issues to experts and businessmen, are active consumer-citizens. It seems that macro-level trust in societal institutions and expert knowledge does not undermine individual-level readiness to change consumption patterns regarding energy issues.

We have shown previously that the level of knowledge and the sense of civic efficacy are not particularly low among supporters of stealth democracy. In fact, support for stealth democracy was higher among citizens who felt that they were knowledgeable on energy issues than among those who were not. The endorsement of stealth democracy (and political consumerism) increased citizens' civil efficacy, i.e. trust in their possibilities to influence energy policy making. Supporters of stealth democracy (and political consumerism) perceived voting in elections as a useful device for influencing energy policy more generally than did non-supporters. However, support for both political consumerism and stealth democracy reflects critical attitude on energy policy making: adherents to political consumerism and stealth democracy were more sceptical than were non-supporters that citizens' opinions were heard in energy policy making (Ruostetsaari, 2018).

In short, political consumerism and stealth democracy cannot be seen mainly as rival and opposite interpretations of electoral participation but rather as complementary modes. Moreover, they cannot be seen as detached attitudes on political involvement: A half of supporters of stealth democracy also endorsed political consumerism. However, stealth democracy can be seen more as a reaction of people who feel powerless in the face of the regime, while the supporters of political consumerism have a higher sense of civil efficacy.

The fact that Finns clearly support stealth democracy $(72 \%)$ more than political consumerism (48\%) can be explained by the characteristics of the Finnish political culture where high trust, by international standards, in political and legal systems, firms and technology (i.e. experts) is associated with low civic efficacy and half-hearted appreciation of democracy (a characteristic of stealth democracy). For instance, according to World Values Survey 2005-2007, Finns' confidence in public sector institutions (parliament, political parties, the national government, the civil service, justice, police and the military) was the highest among 16 older liberal democracies (the second highest in Norway and fifth highest in Sweden), while their overt approval of the democratic political system was the lowest, being the highest among Swedes and Norwegians (Norris, 2011, pp. 88-93).

Support for demand response and prosumerism among adherents to stealth democracy may be explained by the fact that these activities have been presented as important goals towards reforming the energy system by governmental institutions, experts and businessmen - the institutions trusted by supporters of stealth democracy. More generally, our findings indicate that the citizenry as passive actors in policy making, a thesis presented by the theory of stealth democracy, is an inadequate assertion: individuals, as well as conscious consumers, who do not want to personally participate in policy making can be active consumer-citizens in their everyday lives. As far as further research is concerned, we need to understand more profoundly the reasons for that also the supporters of stealth democracy, who are willing to leave the decision-making in the hands of experts, are active energy citizens in their daily lives. It might be that the variables used in our study to measure stealth democracy are not specific enough. More generally, Finns' willingness to support for stealth democracy may be based on or at least encouraged by the misunderstandings of democratic politics (Hibbing and Theiss-Morse, 2005, p. 222): we need 
more information on the level of knowledge that citizens have about normative principles of democratic decision-making processes.

The first implication of this study for energy policy making is that there are (at least in Finland) good preconditions for developing a decentralized energy system: citizens are ready to adopt a more active role as energy citizens in terms of demand response and prosumerism - irrespective of their attitudes on macro-level attitudes on governmental institutions.

Second, citizens' attitudes indicate that their potential for involvement needs to be strengthened in the spirit of energy democracy: the idea of energy democracy needs to be seen in terms of the demand for increased accountability and democratization of the energy sector that was previously not seen as requiring public involvement, and was most often depoliticized and dominated by technocrats (Szulecki, 2017, p. 32). In fact, citizens' firm trust on science, technology and experts, for instance in solving environmental problems caused by energy production and consumption (Ruostetsaari, 2018) may have contradictory effects on energy democracy: while the trust may weaken citizens' activity in energy policy involvement when they are prepared to give experts a great deal of decision-making power in energy policy and who are trusted to make high-quality decisions, the interest in technology increases citizens' readiness to become active energy citizens in their everyday life, for instance as prosumers and users of demand response (Järvenreuna, 2019, p. 79). This everyday activity can, in turn, increase preparedness for energy policy involvement on national and even global level if the opportunity structures create preconditions for it.

However, strengthening energy democracy through demand response and prosumerism is not without its problems: utilization of these devices requires a relatively large amount of resources which depend on the individuals' socio-economic position (Järvenreuna, 2019, p. 79). Thus, energy democracy cannot replace but complement electoral participation as a form of energy policy involvement.

The fact that there was an age bias in our sample compared to the population may have affected the attitudes on demand response and prosumerism. However, the bias among citizens who were between 18 and 29 years (underrepresented) as well as among 45-59- and 60-75-years-old (overrepresented) may have balanced the bias due to that economic resources for active energy citizenship are the scarcest among the youngest and the oldest cohorts. All in all, democratization could strengthen the legitimacy of energy policy making: for instance, still a half of Finns feel that their opinions have not been heard sufficiently in energy policy decisions (Ruostetsaari, 2018).

\section{Note}

1. For the first time in the history of the Finnish electricity market, the wholesale price on Power exchange (Nordpool) was negative in the night time on 10 February 2020. However, for the household consumers, the price was not negative, but for the author, for example, it was $0.265 \mathrm{cent} / \mathrm{kWh}$.

\section{References}

Bengtsson, A. (2012), “Citizens' perceptions of political processes: a critical evaluation of consistency and survey items", Revista Internacional de Sociología, Vol. 70, pp. 45-60.

Bengtsson, A. and Mattila, M. (2009), "Direct democracy and its critics: support for direct democracy and 'stealth democracy' in Finland”, West European Politics, Vol. 32 No. 5, pp. 1031-1048. 
Chubb, J.E. (1983), "Interest groups and the bureaucracy", The Politics of Energy, Stanford University Press, Stanford.

Energy Attitudes (2007), Research report 25.4.2008, Finnish Energy Industries, available at: www.sci.fiyhdys.eas._07/eas-tied07.htms (accessed 27 October 2008).

Eurobarometer (2013), "Flash eurobarometer 363. How companies influence our society: citizens' view", available at: http://ec.europa.eu/commfrontoffice/publicopinion/flash/fl_363_en.pdf (accessed 22 May 2017).

Eurostat (2015), "Quality of life in Europe - facts and views - governance", available at: http://ec. europa.eu/eurostat/statistics-explained/index.php?title=Quality_of_life_in_Europe_-_facts_and_ views_-_governance\&oldid=270643\#Trust_in_institutions_and_trust_in_others $($ accessed $\overline{6}$ January 2017).

Fingrid (2018), "Kysyntäjousto", available at: www.fingrid.fi/sahkomarkkinat/kysyntajousto (accessed 1 March 2018).

Follesdahl, A. (2006), "Political consumerism as chance and challenge", in Micheletti, M., Follesdahl, A. and Stolle, D. (Eds), Politics, Products, and Markets. Exploring Political Consumerism past and Present, Transaction Publishers, New Brunswick, pp. 3-20.

Hibbing, J.R. and Theiss-Morse, E. (2005), "Stealth democracy", Americans' Beliefs about How Government Should Work, Cambridge University Press, New York, NY.

Järvenreuna, V. (2019), "Kohti demokraattisempaa energiajärjestelmää? Kansalaisten näkemykset energiademokratian potentiaalista suomessa", Master Thesis in Political Science, Tampere University, Tampere.

Järventausta, P., Repo, S., Trygg, P., Rautiainen, A., Mutanen, A., Lummi, K., Supponen, A., Heljo, J., Sorri, J., Harsia, P., Honkiniemi, M., Kallioharju, K., Pukkila, V., Luoma, J., Partanen, J., Honkapuro, S., Valtonen, P., Tuunanen, J. and Belonogova, N. (2015), Kysynnän Jousto Suomeen Soveltuvat Käytännön Ratkaisut ja Vaikutukset Verkkoyhtiöille, Tutkimusraportti. Tampereen teknillinen yliopisto, Tampere.

Kestilä-Kekkonen, E. (2014), "Puoluedemokratian haasteet", in Forsberg, T. and Raunio, T. (Eds), Politiikan Muutos, Vastapaino, Tampere, pp. 41-76.

Kotilainen, K. (2020), "Energy prosumers in sustainable energy system", in Leal Filho, W., Azul, A., Brandli, L., Özuyar, P. and Wall, T. (Eds), Affordable and Clean Energy. Encyclopedia of the UN Sustainable Development, Springer, Cham, doi: 10.1007/978-3-319-71057-0_11-1.

Micheletti, M. (2003), Political Virtue and Shopping. Individuals, Consumerism, and Collective Action, Palgrave Macmillan, Basingstoke.

Norris, P. (2011), Democratic Deficit. Critical Citizens Revisited, Cambridge University Press, New York, NY.

OECD (2017), Trust and Public Policy, OECD Publishing, Paris.

Pitkänen, V. and Westinen, J. (2017), "Suomalaisten asenteet ja aktiivisuus energia-asioissa", Energiateollisuus ry, Helsinki, available at: https://energia.fi/files/1684/Suomalaisten_asenteet_ ja_aktiivisuus_energia-asioissa.pdf

Prahalad, C.K. and Ramaswamy, V. (2004), " "Co-creation experiences: the next practice in value creation", Journal of Interactive Marketing, Vol. 18 No. 3, pp. 5-14.

Prontera, A. (2009), "Energy policy: concepts, actors, instruments and recent developments", World Political Science, Vol. 5 No. 1, pp. 1-30.

Rask, M. (2008), "Expanding expertise in science and technology decision making”, Futura, Vol. 27 No. 3, pp. 76-81.

Rucht, D. (1997), “The impact of anti-nuclear power movements in international comparison”, in Bauer, M. (Ed.), Resistance to New Technology. Nuclear Power, Information Technology and Biotechnology, Cambridge University Press, Cambridge, pp. 277-292. 
Ruostetsaari, I. (2010), "Changing regulation and governance of Finnish energy policy-making: new rules but old elites?", Review of Policy Research, Vol. 27 No. 3, pp. 273-297.

Ruostetsaari, I. (2018), “Citizens' support for rival modes of political involvement in energy policymaking. The case of Finland", International Journal of Energy Sector Management, Vol. 12 No. 3, pp. 323-340, doi: 10.1108/IJESM-12-2017-0005.

Ruostetsaari, I. Kotilainen, K. Aalto, P. Harsia, P. Heljo, J. Järventausta, P. Kallioharju, K. Kojo, M. Mylläri, F. Pääkkönen, A. Repo, S. Sorri, J. and Uski, S. (2018), "Suomalaiset sähkön käyttäjinä ja tuottajina: valmius kysyntäjoustoon ja omakohtaiseen sähköntuotantoon”, EL-TRAN analyysi 4, available at: www-el-tran.fi (accessed 1 March 2018).

Science Barometer (2016), Tiedebarometri, Tieteen tiedotus ry, Helsinki.

Sovacool, B.K. (2013), Energy and Ethics. Justice and the Global Energy Challenge, Palgrave Macmillan, Basingstoke.

Sovacool, B.K. and Blyth, P.L. (2015), "Energy and environmental attitudes in the green state of Denmark: implications for energy democracy, low carbon transitions, and energy literature", Environmental Science and Policy, Vol. 54, pp. 304-315, doi: 10.1016/j.envsci.2015.07.011.

Statistics Finland (2016), Energy Supply and Consumption, Statistics Finland, Helsinki.

Stolle, D. and Hooghe, M. (2006), "Consumers as political participants? Shifts in political action repertoires in Western societies", in Micheletti, M., Follesdahl, A. and Stolle, D. (Eds), Politics, Products, and Markets. Exploring Political Consumerism past and Present, Transaction Publishers, New Brunswick, pp. 265-288.

Stolle, D. and Micheletti, M. (2013), "Political consumerism", Global Responsibility in Action, Cambridge University Press, New York, NY.

Szulecki, K. (2017), “Conceptualizing energy democracy”, Environmental Politics, Vol. 27 No. 1, pp. 21-41.

Toffler, A. (1980), The Third Wave, William Morrow, New York, NY.

Vainio, A., Varho, V., Tapio, P., Pulkka, A. and Paloniemi, R. (2019), “Citizens' images of a sustainable energy transition”, Energy, Vol. 183, pp. 606-616.

Valtioneuvosto (2017), "Valtioneuvoston selonteko kansallisesta energia- ja ilmastostrategiasta vuoteen 2030”, Työ-ja Elinkeinoministeriön Julkaisuja 7, Työ- ja elinkeinoministeriö, Helsinki.

\section{Further reading}

Kantola, A. (2011), " “Tyhjää vai täyttä julkista elämää?”, in Kantola, A. (Ed.), Hetken Hallitsijat. Gaudeamus, Helsinki, pp. 164-179.

Schumpeter, J.A. (1959), Capitalism, Socialism and Democracy, 8th ed., Allen and Unwin, London.

\section{Corresponding author}

Ilkka Ruostetsaari can be contacted at: ilkka.ruostetsaari@tuni.fi

For instructions on how to order reprints of this article, please visit our website: 